\title{
Platismatia norvegica - a new lichen record from European Russia
}

\author{
Viktoria N. Tarasova \\ Department of Botany and Plant Physiology, Petrozavodsk State University, Lenin av., 33, 185910 Petrozavodsk, Russia \\ E-mail: vika18@sampo.ru
}

\begin{abstract}
Suboceanic lichen Platismatia norvegica is recorded for the first time in European Russia, in old-growth spruce forest, on the highest point of low-mountain ridge Vetreniy Poyas - Olovgora (Arkhangelsk region).
\end{abstract}

\section{INTRODUCTION}

Platismatia norvegica (Lynge) W. L. Culb. \& C. F. Culb is a broadly foliose lichen in the family Parmeliaceae; it is considered a boreal suboceanic species, occurring in NW Europe (Norway, Sweden, Finland, and Scotland in UK) (Fig. 1), E and NW North America (eastern Canada, mainly Newfoundland, and southeastern Alaska), and occasionally in Asia (Culberson \& Culberson, 1968; Rassadina, 1971; Thell \& Moberg, 2011). In the Russian Federation, the species is currently known only in the southern part of the Far East - the Jewish Autonomous Region, Primorsky Krai and Sakhalin (Tolpysheva, 1990; Skirina, 1995; Chabanenko, 2002; Urbanavichus, 2010). The species inhabits coniferous, mixed coniferous and deciduous, and occasionally deciduous forests where it grows on the bark of pine trees, as well as on rocks and screes (Rassadina, 1971). Outside the Nordic countries the species is mainly an epiphyte of conifers in humid situations (Thell \& Moberg, 2011).

Platismatia norvegica is a red-listed lichen in Sweden and Finland (Thell \& Moberg, 2011), and in some parts of Russia, i.e. Primorsky Krai (The Red Data Book of Primorsky Krai, 2008) and Sakhalin (The Sakhalin Region Red Data Book, 2005). High sensitivity to air pollution and to disturbance of natural habitats (e.g. forest cuttings and fires) of this lichen has been pointed out among the limiting factors restricting the occurrence of the species (Red Data Book of Primorsky Krai, 2008). Distribution pattern of Platismatia norvegica is closely related to the moisture conditions of the habitat (Lidén, 2009). A study conducted in Norway and Sweden demonstrated that in the suboceanic areas population of $P$. norvegica was stronger linked with the microclimatic moisture conditions than in oceanic areas. Both less acidic bark $\mathrm{pH}$ values and close proximity to open water were important for the occurrence of $P$. norvegica in the continental region, while insignificant in the oceanic environments (Lidén \& Hilmo, 2005). There is also a successful attempt to transplant thallus of this species in natural habitats (Lidén et al., 2004).

\section{MATERIAL AND METHODS}

The field work was carried out in June 2012 and 2013, in Arkhangelsk region, Olovgora, which is the highest point of low-mountain ridge Vetreniy Poyas (344 $\mathrm{m}$ a. s. 1.). This ridge is a highland open to sea winds; it is about $200 \mathrm{~km}$ long and $10-15 \mathrm{~km}$ wide $\left(63^{\circ} \mathrm{N}, 36-39^{\circ} \mathrm{E}\right)$, situated along the southern coast of the Onega Bay of the White Sea. The ridge is a part of the Baltic Shield, clearly rising above the surrounding lowlands. The ridge has a steep northern slope, and a flat-lying southern slope, and consists of several ridges $200-300 \mathrm{~m}$ high, elongated to the SE. Olovgora is located $45 \mathrm{~km}$ south of the White Sea. It is formed by exposed at the surface solid Proterozoic crystalline ultramafic rock (komatiitic basalt) conglomerates of different size (Kulikova et al., 2007). The climate is characterized by frequent changes of air masses, causing athmospheric instability. Annual rainfall ranges from 400 to $540 \mathrm{~mm}$, the number of wet days is up to 200 days a year (Gromtsev, 2008).

Old-growth (over 300 years old) spruce forest vegetation of Olovgora has no traces of logging or fire. Forest stand is formed by Picea obovata Ledeb. (66\%) and Betula pubescens Ehrh. (34\%) (Fig. 2). The soil cover is dominated by Vaccinium myrtillus L., V. vitis-idaea L., Ledum 


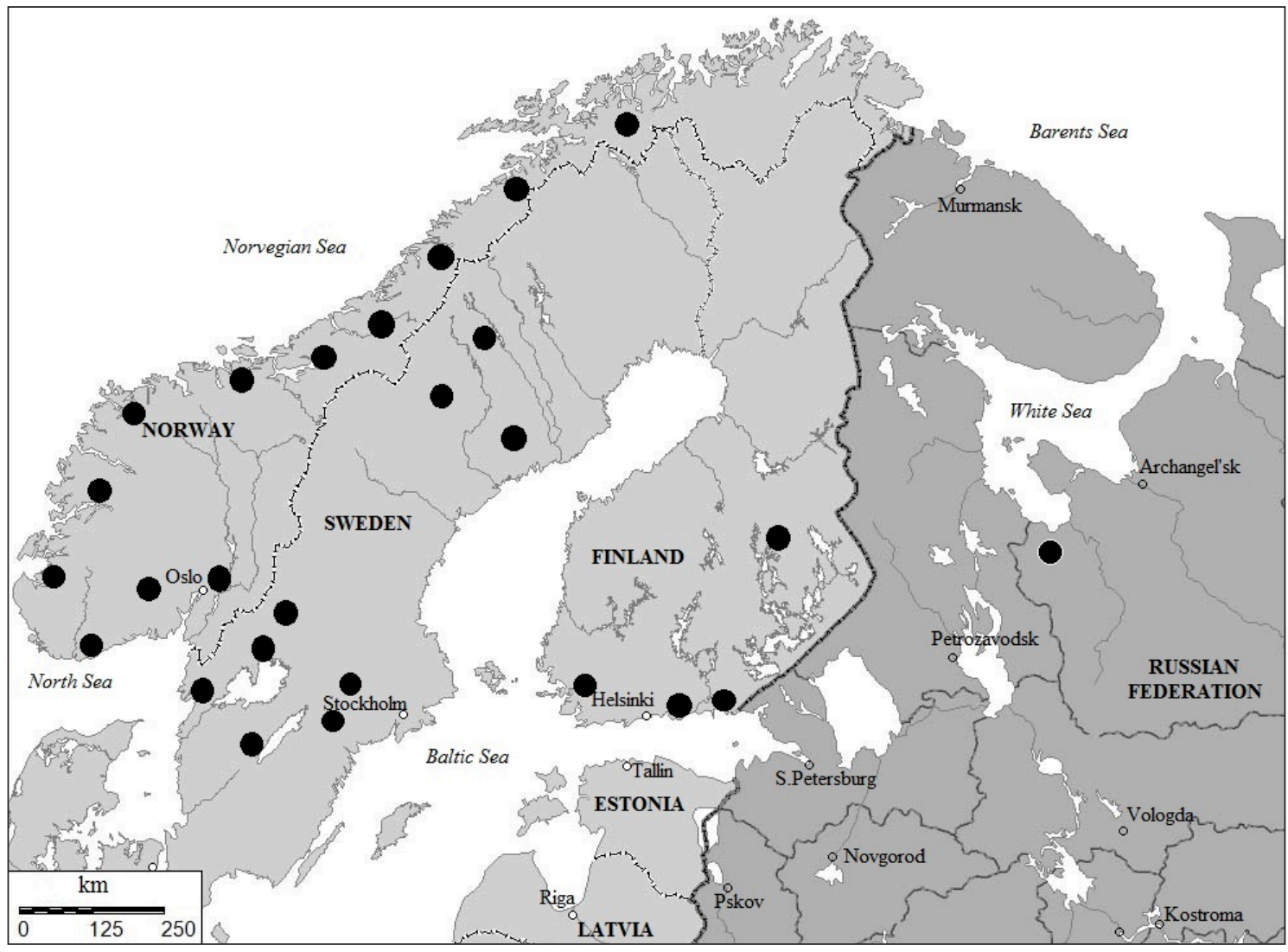

Fig. 1. The distribution of Platismatia norvegica in Northern Europe (according to Thell \& Moberg, 2011, amended). Dots ( $\bullet$ in Fennoscandia indicate the provinces where the species has been recorded, in Russian Federation it marks the exact locality of $P$. norvegica.

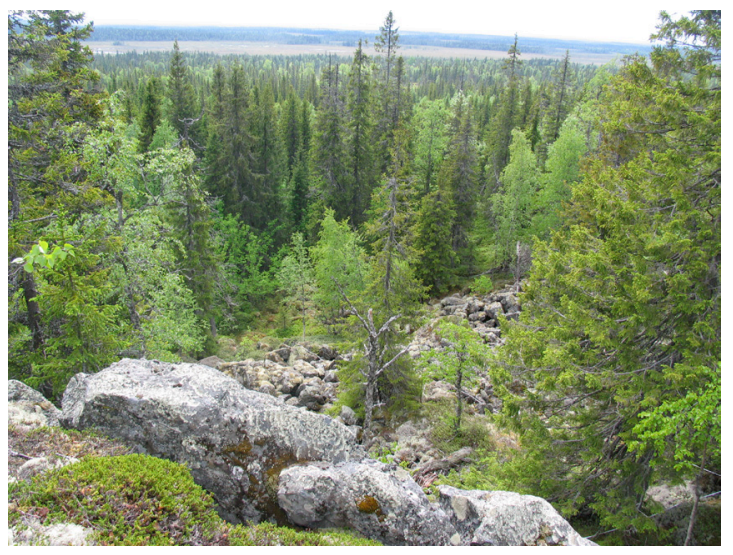

Fig. 2. Habitat of Platismatia norvegica in spruce-birch forest (Olovgora, Arkhangelsk region, Russia). palustre L., and Calluna vulgaris (L.) Hull., as well as a variety of green mosses, liverworts and lichens. The age of forest stand varies between 42-260 years, height of trees $-6-15 \mathrm{~m}$, diameter of trunks (at a height of $130 \mathrm{~cm}$ ) $-13-36 \mathrm{~cm}$. The density of crown is $60 \%$; there is a large amount of dead wood.

\section{RESULTS}

Specimens examined: Russia, Arkhangelsk region, mountain ridge Vetreniy Poyas, Olovgora, middle part of the southern slope $\left(63^{\circ} 24^{\prime} 67^{\prime \prime} \mathrm{N}, 37^{\circ} 00^{\prime} 24^{\prime \prime} \mathrm{E}\right)$, alt. $289 \mathrm{~m}$ a. s. 1., spruce forest, on branches of Picea obovata, 10.06.2012, 11.06.2013 (PZV, herbarium of Petrozavodsk State University).

In the course of detailed study of Olovgora (11 study plots $20 \times 20 \mathrm{~m}$, plus routes covering the 
entire territory of Olovgora), only two samples of Platismatia norvegica $\left(4 \times 8 \mathrm{~cm}^{2}\right.$ and $\left.3 \times 5 \mathrm{~cm}^{2}\right)$ were recorded in the same locality. The samples were found on the lower branches (1-2 $\mathrm{m}$ above ground) of Picea obovata (the trees aged 260 and 159 years) (Fig. 3). 49 other lichen species were recorded on the same trees: Alectoria sarmentosa (Ach.) Ach., Bryoria bicolor (Ehrh.) Brodo \& D. Hawksw., B. capillaris (Ach.) Brodo \& D. Hawksw., B. furcellata (Fr.) Brodo \& D. Hawksw., B. fuscescens (Gyeln.) Brodo \& D. Hawksw., B. implexa (Hoffm.) Brodo \& D. Hawksw., B. nadvornikiana (Gyeln.) Brodo \& D. Hawksw., Calicium glaucellum Ach., C. viride Pers., Chaenotheca chrysocephala (Turner ex Ach.) Th. Fr., C. subroscida (Either) Zahlbr., C. trichialis (Ach.) Th. Fr., Chaenothecopsis consosiata (Nádv.) A.F.W. Schmidt, C. fennica (Laurilla) Tibell, Cladonia bacilliformis (Nyl.) Glück, C. cenotea (Ach.) Schaer., C. deformis (L.) Hoffm., C. digitata (L.) Hoffm., C. pleurota (Flörke) Schaer., Cyphelium inquinans (Sm.) Trevis., Hypocenomyce friesii (Ach.) P. James \& Gotth. Schneid., Hypogymnia austerodes (Nyl.) Räsänen, H. bitteri (Lynge) Ahti, H. physodes (L.) Nyl., H. tubulosa (Schaer.) Hav., H. vittata (Ach.) Parrique, Imshaugia aleurites (Ach.) S.L.F. Meyer, Japewia subaurifera Muhr \& Tønsberg, Lecidea turgidula Fr., Lepraria jackii Tønsberg, Loxospora elatina (Ach.) A. Massal., Melanelia olivacea (L.) Essl., Microcalicium disseminatum (Ach.) Vain., Mycoblastus sanguinarius (L.) Norman, Ochrolechia cf. androgyna (Hoffm.) Arnold,

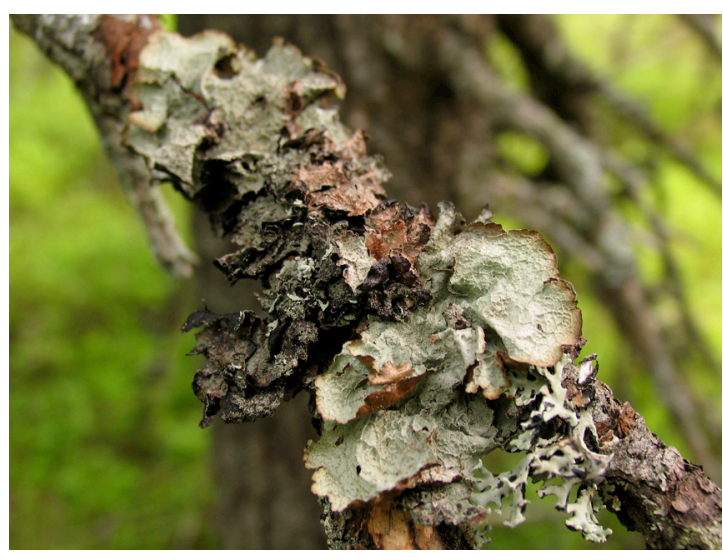

Fig. 3. Platismatia norvegica on branch of old spruce (Olovgora, Arkhangelsk region, Russia).
Parmelia sulcata Taylor, Parmeliopsis ambiqua (Wulfen) Nyl., P. hyperopta (Ach.) Arnold, Pertusaria amara (Ach.) Nyl., Platismatia glauca (L.) W.L. Culb. \& C.F. Culb., Pseudevernia furfuracea (L.) Zopf, Tuckermannopsis chlorophylla (Willd.) Hale, Usnea dasypoga (Ach.) Nyl., U. subfloridana Stirt., Varicellaria rhodocarpa (Körb.) Th. Fr., Vulpicida pinastri (Scop.) J.-E. Mattsson \& M.J. Lai, Xylographa pallens Nyl., X. parallela (Ach.: Fr.) Fr., and X. vitiligo (Ach.) J.R. Laundon.

The presence of $P$. norvegica in the study area is likely to be explained by the proximity to the White Sea, undisturbed plant communities and suitable microhabitat conditions. We assume that $P$. norvegica needs to be protected in this locality.

\section{ACKNOWLEDGEMENTS}

I would like to express our gratitude to our colleagues G. P. Urbanavichus (Institute of North Industrial Ecology Problems KSC RAS, Russia) and J. Hermansson (Department of Physical Planning, Ludvika municipality, Sweden) for the assistance in species identification, and my colleges A. V. Sonina and V. I. Androsova and students of Petrozavodsk State University for their help in collecting field data. The study was partially supported by the Ministry of Education and Science of Russian Federation.

\section{REFERENCES}

Chabanenko, S. I. 2002. Synopsis of lichen flora of the south of the Russian Far East. (In Russian). Vladivostok, Dal'nauka. 232 pp.

Culberson, W. L. \& Culberson, C. F. 1968. The lichen genera Cetrelia and Platismatia (Parmeliaceae). Contributions from the United States National Herbarium. 34(7): 449-558.

Gromtsev A. N. 2008. Climate. In: A. N. Gromtsev (ed.). Rupestrian landscapes of White Sea Karelian Coast: natural characteristics, economic utilization, conservation. (In Russian). Petrozavodsk, Karelian Research Centre of Russian Academic Science. 212 pp.

Kulikov, V. V., Kulikov V. S. \& Bychkova Y. V. 2007. Revising the volcano-plutonic system "Volcano Loach - Ruyga intrusion”. (In Russian). Geology and Mineral Resources of Karelia. Proceedings KRC RAS. Ed. 10. Petrozavodsk, pp. 69-81.

Lidén M. 2009. Restoration of endangered epiphytic lichens in fragmented forest landscapes: the importance of habitat quality and transplantation 
techniques. Ph.D Thesis. Umeå, Swedish University of Agricultural Sciences, Department of Forest Ecology and Management. 46 pp.

Lidén, M. \& Hilmo, O. 2005. Population characteristics of the suboceanic lichen Platismatia norvegica in core and fringe habitats: relations to macroclimate, substrate, and proximity to streams. The Bryologist 108(4): 506-517. http://dx.doi. org/10.1639/0007-2745(2005)108[0506:PCOT SL]2.0.CO;2

Lidén, M., Pettersson, M., Bergsten, U. \& Lundmark, T. 2004. Artificial dispersal of endangered epiphytic lichens: a tool for conservation in boreal forest landscapes. Biological Conservation 118(4): 431-442. http://dx.doi.org/10.1016/j. biocon.2003.09.026

Rassadina, K. A. 1971. Family Parmeliaceae. In: I. I. Abramov (ed.). Handbook of the Lichens of the USSR. 1. (In Russian). Leningrad, Nauka. Pp. 285-386.
The Red Data Book of Primorsky Krai. Plants. 2008. (In Russian). Vladivostok, Apelsin. 688 pp.

The Sakhalin region Red Data Book. Plants. 2005. (In Russian). Yuzhno-Sakhalinsk, Sakhalin Publishing House. 348 pp.

Skirina, I. F. 1995. Lichens Sikhote-Alin Biosphere area. (In Russian). Pacific Institute of Geography, Far East Branch of Russian Academic Science, Vladivostok, Dal'nauka. 132 pp.

Thell, A. \& Moberg, R. 2011. Nordic Lichen Flora. Vol 4. Parmeliaceae. Uppsala, Uppsala University, Nordic Lichen Society. 184 pp.

Tolpysheva, T. Y. 1990. Platismatia norvegica (Lynge) Culb. et C. Culb. - a new species of lichen for the USSR. (In Russian). Novitates systematicae plantarum non vacsularium 27: 117-118.

Urbanavichus, G. P. 2010. A checklist of the lichen flora of Russia. (In Russian). St. Petersburg. 194 pp. 